\title{
Study on the Enlightenment of MOOCs on College English Curriculum Setting*
}

\begin{abstract}
XU Jun
Huanghuai University, Henan, China

MOOC, as a new means of education informatization, does impact the traditional college English curriculum settings, which needs to adapt to the development trend of online education. Through the analysis of the domestic and foreign literature review, it concludes that our country's college English curriculum should introduce more MOOCs, and make international MOOCs become one parts of their own curriculums. Students can choose any English course with their own interests. And college English curriculum teachers should improve their skills and become more specialized to adapt to the new trend of world higher education.

Keywords: MOOCs, college English curriculum group, curriculum setting
\end{abstract}

\section{Introduction}

Since 2012, the international MOOCs have grown rapidly. And lots of free curriculums from the world's top universities opened to the global learners. They could learn lots of classic courses which involve the various fields of natural science and humanities and social science. And in 2013, China's colleges and universities began to join the camp of international MOOCs and started to build their own MOOCs. So the college English teaching is no exception. MOOCs bring great impacts to it. However, the setting of college English curriculum must meet the need of new trend of online education.

\section{The Analysis of Research Status of MOOC at Home}

MOOC is the short for "Massive Open Online Course", which refers to a kind of new curriculum model in the field of education. It is firstly proposed by Dave Cormier and Bryan Alexander in 2008. It is intended to break the limitation of the traditional education's restriction by time, space, and person through the platform of network. Using "MOOC" or "massive open online course" as the keywords in CNKI (China National Knowledge Infrastructure: China Academic Journal Network Publication) to retrieve, it obtained 288 Chinese academic papers about MOOC between 2010 to June 2015. From the number of views, the Chinese academic literatures are far less than the English ones, which corresponds with the development of related practices and researches in domestic and foreign countries. To sum up 288 Chinese literatures related to MOOC, the current research on it mainly focuses on the following aspects:

\footnotetext{
* Acknowledgements: This project is supported by the Social Science Association of Henan Province (No.: SKL-2015-1399). XU Jun, lecturer, master, College of Foreign Languages, Huanghuai University.
} 


\section{The Development of MOOCs and Its Influence on Traditional (Higher) Education}

WANG Wen-li (2013) discusses the impact of MOOC on the development of higher education, and considers that opportunities and challenges coexist. GU Xiao-qing, HU Yi-ling, and CAI Hui-ying (2013) discuss the possibilities of MOOC localization and the challenges of the localization process. These studies analyze the development of MOOCs and the relevance with traditional education from different angles deeply. It has much more help for the later researches about the development of MOOC and its characteristics. But for the foreign literatures, the researchers pay more attention to the influence of MOOC on the learners of the traditional universities.

\section{MOOC Provides the Platform and Technology Environment}

The earliest and most common researches in domestic about MOOC are the MOOC platforms and technology environment. WU Shu-ping (2013) expounds the impact of MOOC on the construction of "cloud" learning environment, and puts forward the framework of the MOOC model of it on the basis of systematic analysis in MOOC, which treats the "cloud" learning environment as the breakthrough point. But foreign literatures concern more about the relevance between the technologies of MOOCs and learners. For example, Dorsa Sadigh (2012) concerns the automation of problems, solutions and grading, etc., in the MOOCs. Ingede Waard (2013) compares the influences of the applications of mobile technology on the students' interactions of MOOCs.

\section{Teaching and Learning in MOOCs}

From 2012, the domestic researches begin to concern the teaching and learning on MOOCs. FAN Wen-qiang (2012) analyzes the advantages and disadvantages of MOOCs from the perspective of learning support. Foreign literatures have lots of research on the teaching and learning of MOOC with more details, especially on the aspects learners and teachers' experiences of MOOC and learning evaluation, etc. Cathy Sandeen (2013) studies the learning evaluation in MOOCs, which believes that it faces variety challenges, and getting the processes and results of the evaluation is still a problem.

According to these analyses of the relevant literatures, MOOC's practice and research are in the rise. Although it harvests a wealth of achievements, there are still many shortcomings. Two aspects of MOOC research at least need concern: (1) The overall number of studies is less. Comparing the number of literatures at home and abroad, domestic research on MOOCs has a lot of space to rise; and (2) The depth and width of related researches on MOOCs are insufficient, lacking of large-scale and comprehensive studies, which reflects the lack of relevant practice in the accumulation and the depth and breadth of the research.

\section{Study on the Enlightenment of MOOCs on College English Curriculum Settings in China}

MOOC, as a new means of education informatization, does impact the traditional college English curriculum settings, which needs to adapt to the development trend of online education. Therefore, MOOC has great significance to college English teaching whether in theory or in teaching practice. In this paper, through the combing and generalizing of lots of literatures, it gets the research trends of this relevant topic; and taking the traditional college English curriculum settings as an example, it describes the MOOC and its effects in English teaching. Comparing to the curriculum setting of MOOC, it discusses the large-scale network open course 
(MOOC) and its learning support based on the Connectivism. Through the analysis of this two curriculum settings, it reveals the essence of the experience systematically and comprehensively, which makes it rise to the height of theory. It can be used to set up the college English curriculum groups which meet the need of Chinese national conditions.

While learning to adapt to the development of higher education in the world, we still need to build the development of MOOCs in our country. Through the macro and micro teaching design of foreign MOOCs, we should build a large scale of our college English online courses. The learners can not only improve their English level during learning knowledge, but also implement English learning based on the contents easily.

And for the teachers, with MOOCs in their teaching plans, it can optimize their structure of knowledge and practice strategies effectively, and then improve their teaching qualities and teaching effects. On the background of domestic and foreign research status of MOOCs, the research focuses on the curriculum settings of our college English course in following aspects:

\section{Establishing Massive Open Online College English (MOOCE)}

At present, the college English curriculum is mainly set according to "College English Curriculum Requirements" (2007) of Ministry of Education in our country. The contents of college English course in colleges and universities are generally composed of comprehensive English and college English video-aural-oral course, i.e., General English. None of them can set up a college English course that meets all the needs of all the students according to the Curriculum Requirements. So, with the rise of MOOCs, we can establish the "Massive Open Online English College (MOOCE)”, which includes general English, ESP (English for Specific Purpose) and EAP (English for Academic Purpose). Learners can choose any related courses to learn according to their own interests and basis.

\section{Cooperating With International Universities and Strengthening the Management of MOOC Platform}

With appearance of more and more international MOOCs, the learners can select any of them to learn directly in our country. And they can communicate through the online platform with the lecturers and their teachers anytime. Our universities can also cooperate with international universities. Through increasing administrator privilege of the course platform, teachers can track students' learning situation, assess learning results, and guarantee them to achieve the study goal. MOOC, as a part of the college English curriculum, makes the goals of exchanging and sharing teaching resources come true, which promotes the internationalization of college English curriculum, to ensure it to keep pace with the times.

\section{Changing the College English Curriculum Restrictions of Contents and Giving the Recognition of Students Who Take MOOCs After Class}

After the construction of "Massive Open Online College English", the learners can choose any English courses with their own interests freely. Universities and colleges can regulate the English class curriculum credits that the students must meet the achievement, but not the contents of the course. It can take care of the students' individual differences, also make the students" English learning from the "external force" to "domestic demand".

\section{Enhancing Abilities of College English Teachers and Ensuring Them More Specialized}

The MOOCs in college English curriculum promote the teachers to pay more attention to improve their professional development. Through broadening the knowledge, deepening the professional theory, and 
improving the teaching idea, teachers need to improve and enhance their qualities and abilities constantly. At the same time, the role of college English teachers will change from the leaders of class to the supporters, managers, and the ones who are in charge of answering questions for the students. And the students choose the National college English courses from the online platform. They can obtain the questions answering in their own colleges. Each teacher needs to set up the answering questions classes according to their own interests and specialty to help students finish English courses. Several years later, the college English teachers will become to the experts in a certain field, but not just ordinary English teachers.

\section{Conclusion}

The college English curriculum setting is different from the traditional curriculum setting. And the new "Massive Open Online College English" has the basic characteristics of MOOC, such as, large-scale, open, online, free, and so on. And the design of curriculum is in line with the practical, instrumental, and humanistic of the requirements of college English curriculum.

The "Massive Open Online College English Curriculum" has a structured curriculum design and learning plan which can meet the learning rules of network learners. Through the interaction of the learning process, it can improve the learners' autonomy, help learners build their learning network, and then construct an organic learning ecological network.

The teaching mode of MOOC promotes the integration of traditional classroom and network school. The proportion of "proselytizes, instructs, dispels doubt" in teachers' duty has a change. Online education provides evidence for the reorientation of teacher's role and injects new vitality for the teaching reform of University.

\section{References}

HAO, D. (2013). The analysis of MOOC literature review status in domestic. Distance Education in China, 153(11), 42-50.

LI, X. D. (2014). The challenge and countermeasure to the teaching ability of the teachers in colleges and universities for MOOCs. Journal of Nanjing University of Science and Technology (Social Science Edition), 27(2), 89-92.

LIAN, X. Y. (2014). On the reform of post college English curriculum under the influence of MOOCs. Journal of Fujian Medical University (Social Science Edition), 15(3), 54-57.

MA, W. L., \& ZHANG, X. P. (2014). The study of the enlightenment of the large-scale open course (MOOCs) to the Chinese college English curriculum setting. E-education Research, 249(1), 52-57.

MA, W. L., \& HU, J. S. (2014). On the impact of international MOOCs and redesign of college English curriculum. Media in Foreign Language Instruction, 157(5), 48-54.

WANG, W. L. (2013). MOOC's development and its influence on higher education. Jiangsu Higher Education, 33(2), 53-57. 